\title{
Development of Flood Defense Alternaives for the Beach of Deir El Balah Camp, Palestine
}

\author{
Mazen Abualtayef \\ Environmental Engineering Department, the Islamic University of Gaza, Palestine \\ https://doi.org/10.33976/JERT.8.2/2021/1
}

\begin{abstract}
The development along the coastal zone has led to the host of problems such as erosion, siltation, flooding, loss of coastal resources and the destruction of the fragile marine habitats. The erosion threatens the coastal zone, which affects people's economic, tourist, and recreational life. The main reason of the erosion is due to Khan Younis breakwater and the sea waves working on empty the beachy sand, thereby flooding and scouring the area as it ebbs and removing part of the unconsolidated sand. This study uses Geographic Information System to detect changes in the coastline along Deir El Balah coast during the 1972-2020 period. Shoreline change rates in the form of erosion and accretion patterns are quantified. In addition, four alternatives are proposed to to mitigate the current problems raised by repeated flooding and erosion through reefballs, cubes, geotubes and seawalls and analyze their impacts on coastal protection to provide the best possible mitigations in environmental, economical and engineering terms. Multi criteria analysis is used to assess the alternatives with respect to criteria that capture the key dimensions of the selection process. Multi criteria have been selected and addressed the most important factors when planning, designing, financing, and implementing coastal protection measures. Based on the analysis, the best alternative of three-row reefballs submerged breakwaters is recommended.
\end{abstract}

Index Terms - Flood Defense, Erosion, Offshore Breakwater, Gaza

\section{INTRODUCTION}

Gaza's Mediterranean coast, which stretches for around 40 $\mathrm{km}$, is rich in coastal resources. Coastal development has resulted in hosting problems, including increased flooding, erosion, siltation, depletion of coastal resources, and the degradation of vulnerable marine ecosystems. In some parts along the coast of Gaza strip, the coastal erosion is the most serious problem. The erosion threatens the structure, buildings, roads and other installations located directly on the coast. On other words, erosion threatens the coastal life, which affects people's houses, economic, tourist, and recreational life as well as the daily life [1].

Fixed buildings near the beach are being increasingly exposed to the direct impact of storm waves, and will be damaged unless costly protective measures are taken against erosion. It has long been assumed that the underlying rate of long-term sandy beach erosion is two orders of magnitude faster than the rate of sea level rise, implying that any substantial rise in sea level would result in a significant increase in sea level [2].

Developing future shoreline change projection necessitates a detailed understanding of the underlying coastal processes. These processes are largely caused by the interaction of mean sea level, waves, storm surges, and tides, all of which are influenced by global and regional climate change and whose variability grows over time [3]. Coastal ecosystems are being threatened by sea level rise and wave action. The restoration of wetlands to preserve shorelines has been touted as a win-win strategy for humans and nature, but field evidence for the wetland protection purpose, as well as an understanding of its background dependence, are rare [4].

The coastal region usually concentrates better social, economic and recreational opportunities [5]. It is of great importance for the natural environment and economic development, in spite of presenting higher risk of natural disasters, such as tsunamis, extreme waves and coastal erosion [6]. In recent decades, the coastal region was changing continuously under the roles of anthropogenic activities such as breakwaters.

The ignoring of beach erosion in Gaza strip leads to aggravation this problem and increasing the danger on the coastal. So to increase the protect of the beach, there are a lot of methods to reduce the erosion such as seawall, groins and breakwater but the suitable methods and the lowest cost should be chosen, and trying to have a beautiful landscape [7]. Gaza's coastal zone is a narrow strip of land that is rapidly expanding, and the growth rate is attributed to its potential for a variety of economic activities and the pressures of urbanization [8].

\section{Impacts of erosion on coastal structures and beaches:}

During the last few years, the beach faced bad weather conditions due to climate change (high waves and strong currents) led directly to many of the problems that collapse and come because of beach erosion continuous years ago along the Gaza beach.

A site visit was conducted on June 8, 2020 to the areas that were severely affected along Deir El Balah Beach, where the 
damage was inspected and their existing situation was assessed. Many areas along the Deir El Balah coast suffer from the disappearance of the beach erosion, which poses a great danger to the road, structures, properties and citizens, beside the safety, environment and beauty of the beach. The following images show the damage to the Fishing Port in Deir El Balah after the severe weather conditions, which is located $1.4 \mathrm{~km}$ to the south of the study site. During the site visit, the head of Fishermen's Union explained the impacts of recent wave attacks during the last two years on the port buildings and dunes as well as the mitigation measures to support the building foundations.

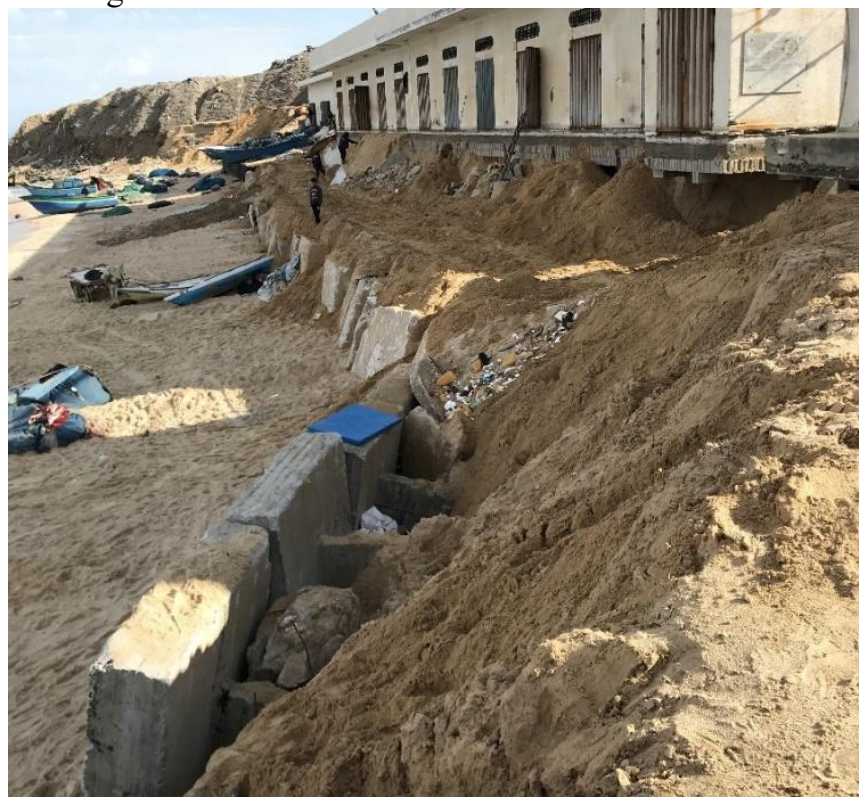

Fig. 1. Wave attacks of the Fishery Port at Deir El Balah (January 16, 2020)

Furthermore, on January 16, 2020, a site visit to beach club at Deir El Balah (located $3.4 \mathrm{~km}$ to the south of study site) was performed immediately after last wave attacks. The club has witnessed sever beach erosion of the cliffs and coast, where the landscaping of the club was collapsed as shown in Figure 2.

The citizens living in the Deir EL Balah camp have faced flooding of their houses in the last storms. Therefore, the construction of flood defense at the beach in front of Deir El Balah camp is at top priority to prevent the repeated seawater flooding in the winter seasons and to find a proper space to the families who need to set in the front of the beach. The flood defense should be planned to target these needs raised by the people by constructing a concrete barrier, which takes into consideration the recreational perspectives.

The main aim of the study is to examine coastal protection techniques against erosion and contribute to improving and developing coastal areas and to support tourism. Several offshore breakwater alternatives were analyzed their impacts on coastal protection to provide the best possible solutions in environmental, economic and engineering terms.

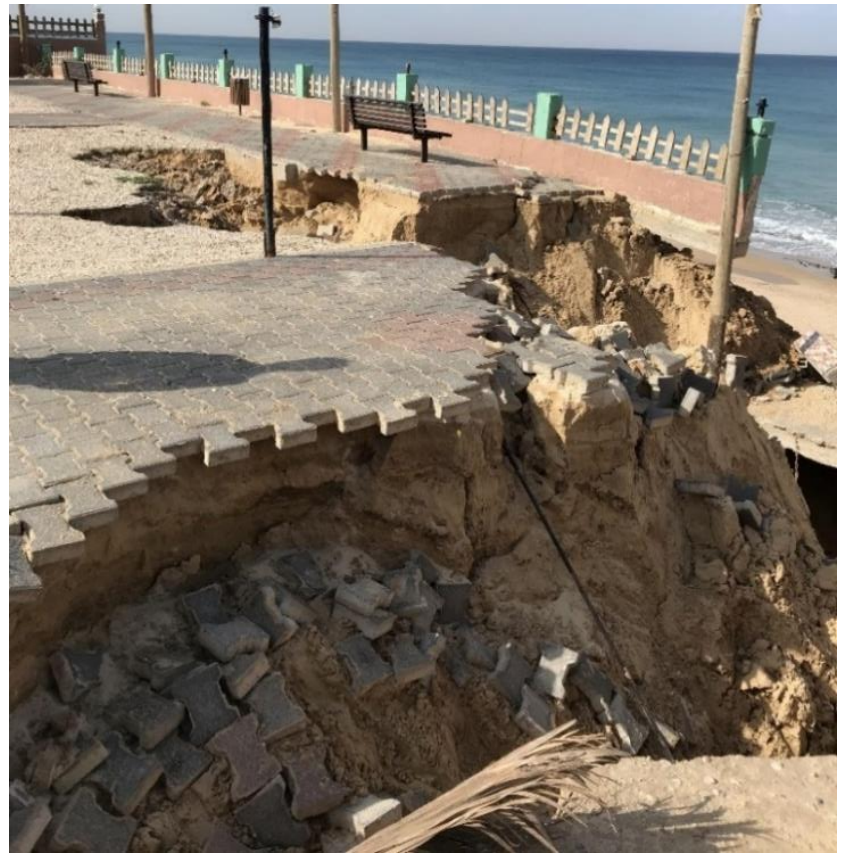

Fig. 2. Wave attacks of the Beach Club at Deir El Balah (January 16, 2020)

\section{Materials And Methods}

Existing baseline conditions of the study area were identified in order to understand the nature of the problem. These include information on location and topography, climate, bathymetry, coast and seabed characteristics, sediment transport, waves, tides and sea level rise, currents, wave runup, erosion, flooding, and social and economic activities.

\subsection{Location and topography}

Available topographic points of the study area have been collected, in order to acquire ground level for identifying the flood area and coastal defense. The existing topography for the study area is illustraed in Figure 3. The figure shows the location of planned coastal defense as well as the proposed location of the offshore breakwaters.

\subsection{Climate}

Temperature: Deir El Balah is located at the middle part of Gaza Strip, which is considered within the arid desert climate. The average daily mean temperature ranges from $25^{\circ} \mathrm{C}$ in summer to $13^{\circ} \mathrm{C}$ in winter [9].

Rainfall: In Deir El Balah Governorate, similar to the Gaza Strip, there are two well defined seasons, the wet season starting in October and extending into April, and the dry season extending from May to September. The rainy season extends from about mid of October to the end of March, with essentially no rain falling in the remaining months. The annual average 5-year rainfall in Deir El Balah governorate is about 300 $\mathrm{mm}$ for the last five years [10].

Winds: The predominant wind direction in Gaza is through NW with more than $28 \%$ of the time. The wind speed is considered calm, as the most speeds are below $5 \mathrm{~m} / \mathrm{s}$. The weather 
in the winter season is dominated by cyclones passing in easterly directions. This results in rather unstable conditions, the most frequent winds occurring from directions between SW and NE. These winds are often strong and generate high waves during the winter season [11].

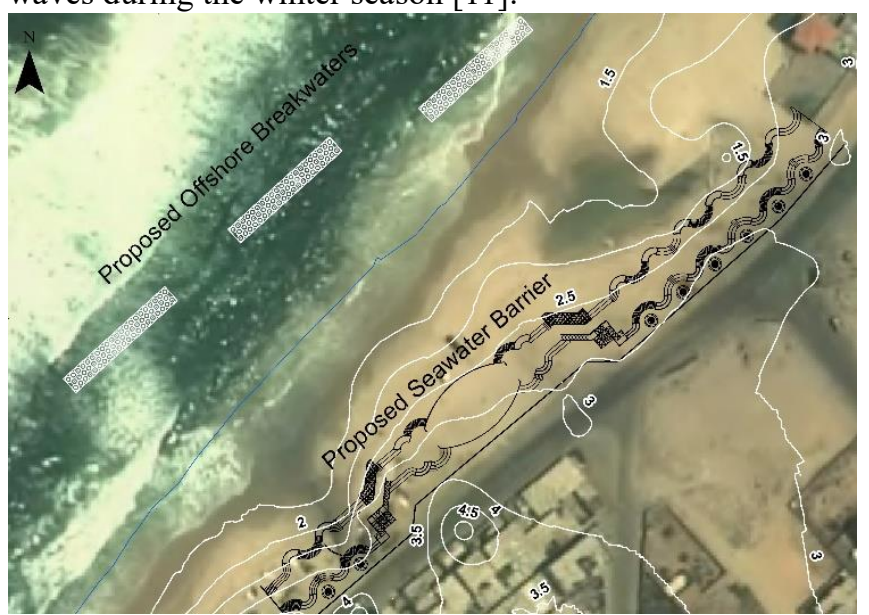

Fig. 3. Existing topography contour map for the study area

\subsection{Bathymetry}

The site-specific bathymetric survey of the study area was conducted on 9 July 2020 within an area of $200 \mathrm{~m}$ offshore by $300 \mathrm{~m}$ alongshore as shown in Figure 4.

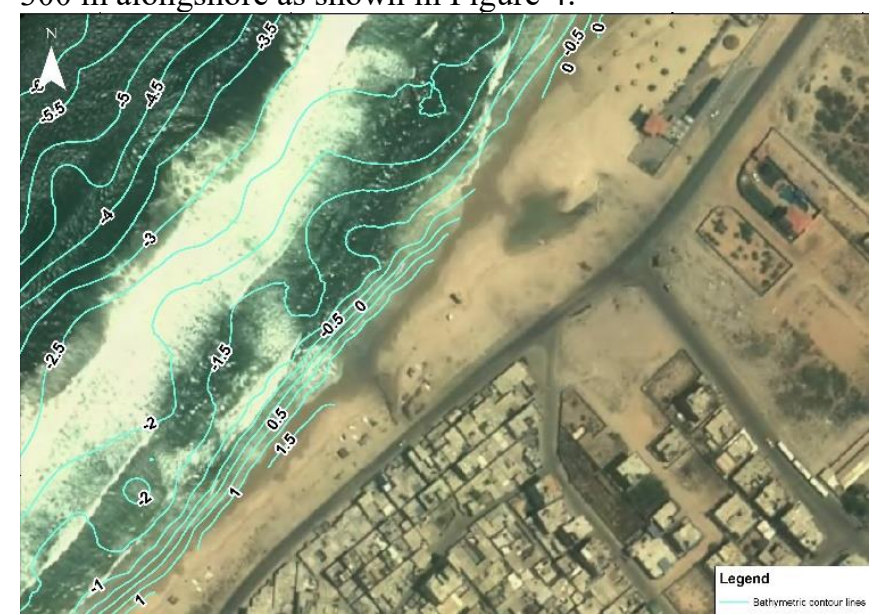

Fig. 4. Bathymetric contour map for the study area (July 2020)

Results of the survey showed that the seabed off the study area has an average slope of about 1 in 40 between 0 and 200 $\mathrm{m}$ offshore. The seabed level, although following a general pattern, can be subject to seasonal changes depending on waves, currents and supplied sediment. The visual inspection by the surveyor showed a sandy bed. Therefore, the stability of submersed breakwater units may be affected by local currents causing scouring near and under these units. Thus, the use of geotextile sheet as a lining material is required to enhance the structure stability.

\subsection{Coast and seabed characteristics}

Moving from beach to the coastal profile, the coastline can be divided into the seabed, the beach, the dune face or coarse sand cliffs, and the adjacent body of the dune. The coastal profile consists of erosion-resistant formations of rock and coarse sand protrude, on the seabed, on the beach, and in the cliffs. On the beach especially near the waterline of the Gaza shoreline on many places coarse sand outcrops and rocky ridges can be seen, which works well to reduce erosion. Where these hard layers are covered only by a relatively thin layer of sand, a retreating coastal profile will gradually consist of an increasing amount of erosion-resistant surface.

The identification of erodibility and composition of the steep coarse sand cliffs along the Gaza coast is important. These cliffs themselves are, somewhat, able to delay the erosion tendency. If these cliffs are attacked by waves and locally collapsed, the eroded kurkar material will feed the beach with a mixture of very fine to very coarse sediment. The fine particles are moved to deep water, whereas the coarse particles work as an armour layer, protecting the freshly exposed coarse sand cliff face during some time.

The Gaza strip seabed is composed of sand, locally slightly cemented, light gray color, with locally shell fragments. Soil investigation report for the study site (issued on 2 March 2020) states that the soil profile encountered in this investigation for the boreholes under buildings consists of sand layer at top followed by a clayey silty sand layer then sand layer. The grain size $\left(D_{50}\right)$ of top layer ranges from 260 to $280 \mu \mathrm{m}$ for borehole $\mathrm{BH} 1$ to borehole $\mathrm{BH} 3$, respectively. For grain sizes bigger than $150 \mu \mathrm{m}$, the erosion rate decreases as the grain size increases [12]. Therefore, the beach off the study area is considered to have medium to high erosion rates.

\subsection{Sediment transport}

Gaza coastal zone is part of the more extensive Nile littoral cell, which extends from the Nile Delta in Egypt. This cell comprises of quartz, sand, silt and clay sediment derived from the Nile Delta by longshore sediment transport, which transports sand by waves and currents north and eastward along the Sinai coast towards Gaza. Therefore, significant amounts of sediment may transfer to the coastal and seaward areas. The longshore sediment transport of about $200,000 \mathrm{~m}^{3} / \mathrm{year}$ was estimated [13].

\subsection{Waves}

Waves' historical data for Gaza are based on wind statistics and fetch considerations, which show that the dominant wave direction is the north-west. Table 1 shows the significant wave height for various return periods [14].

\section{TABLE 1}

Significant wave height for various return periods

\begin{tabular}{|c|c|c|c|c|c|c|}
\hline $\begin{array}{c}\text { Significant wave } \\
\text { height }\end{array}$ & \multicolumn{7}{|c|}{ Return period (year) } \\
\cline { 2 - 7 } & 1 & 5 & 10 & 25 & 50 & 100 \\
\hline Open sea, Hs (m) & 6.5 & 7.8 & 8.3 & 9.0 & 9.6 & 10 \\
\hline
\end{tabular}

\subsection{Tides and sea level rise}

The Mediterranean tidal range is very small. From an ecological and morphological perspective, this means that the intertidal zone is very small, and is influenced mainly by wave 
action rather than by tidal processes. The effect of meteorological variations on sea level may often be greater than astronomical tides. In the Mediterranean, the combined effect of barometric pressure variations, storm surges and waves can reach values that are of the same order as the tidal variations. Table 2 shows the tidal and meteorological data for Gaza coast [15].

TABLE 2

Astronomic tide and meteorological table for Gaza

\begin{tabular}{|l|c|c|}
\hline \multicolumn{1}{|c|}{ Astronomical type } & Symbol & Level (MSL) \\
\hline Max sea level* & & $+0.93 \mathrm{~m}$ \\
\hline Max high surge level* & & $+0.71 \mathrm{~m}$ \\
\hline Highest astronomical tide & HAT & $+0.45 \mathrm{~m}$ \\
\hline Mean high water in spring & MHWS & $+0.35 \mathrm{~m}$ \\
\hline Mean high water in neap & MHWN & $+0.15 \mathrm{~m}$ \\
\hline Mean sea level & MSL & 0 \\
\hline Mean low water in neap & MLWN & $-0.15 \mathrm{~m}$ \\
\hline Mean low water in spring & MLWS & $-0.25 \mathrm{~m}$ \\
\hline Lowest astronomical tide & LAT & $-0.35 \mathrm{~m}$ \\
\hline
\end{tabular}

\subsection{Currents}

Tidal currents in the Eastern Mediterranean are relatively weak. The general circulation is oriented counter-clockwise most of the time, with current speed decreases towards the shore due to the geostrophic current and shelf waves. Currents of about $1.0 \mathrm{~m} / \mathrm{s}$ have been measured [16]. However, typical current mean velocities are $0.05-0.10 \mathrm{~m} / \mathrm{s}$ [17]. The current speed fluctuates between zero and $1.00 \mathrm{~m} / \mathrm{s}$, and the dominant current direction is $31^{\circ}$ to the north [18].

\subsection{Wave Run-up}

Extreme weather events bear a significant impact on coastal human activities. Forecasting the action of sea storms on coastal structures and beaches is an important tool to mitigate their effects. To this end, with particular regard to low coasts and beaches, we will use empirical formula to evaluate beach wave run-up levels and beach flooding during a storm.

The wave run-up can reach beach elevation about $+2.0 \mathrm{~m}$ MSL during high storms for a significant wave height of $>5$ $m$ as per Hunt formula [19], which also includes the wave setup and storm surge. The formulation of run-up height can be calculated from the incident waves. Hunt empirical formulas, $R u$ includes the wave set-up:

$$
\begin{gathered}
\frac{R u}{H o}=\xi \\
\xi=\frac{\tan \beta}{\sqrt{\frac{H o}{L o}}} \\
L o=\frac{g T^{2}}{2 \pi}
\end{gathered}
$$

where,

Ho is the deep-water significant wave height

$\mathrm{T}$ is the wave period

Lo is the linear theory deep-water wavelength

$\beta$ is the beach slope angle

$\xi$ is the Iribarren number or surf similarity parameter
$\mathrm{Ru}$ is the wave run-up

The calculated run-up based on Hunt formula was $1.02 \mathrm{~m}$. However, the local people have witnessed a run-up of $+4.0 \mathrm{~m}$ elevation on the beach dune $(60-70 \mathrm{~m}$ away from the shoreline) during the last storms. Therefore, the study is rely on the local observed figures in which the run-up of $4 \mathrm{~m}$ is considered in the design.

\subsection{Environmental Conditions}

This section highlights the existing key environmental conditions of the study area.

\section{a. Erosion}

The coastal zone of the Gaza Strip is a narrow piece of land lying on the eastern coast of the Mediterranean Sea. The study area covered the beach stretch off $210 \mathrm{~m}$ of the northern part of Deir El Balah Camp. The shoreline changes between 1972 and 2020 were analyzed using remote sensing and GIS tools, where satellite Landsat and aerial images for the Mediterranean coast of Gaza were acquired for different years covering a time span of 48 years. The images were acquired in for various periods and in good quality, with no effective clouds, three images were acquired as shown in Table 3.

TABLE 3

Satellite images source and resolutions

\begin{tabular}{|l|c|c|c|c|c|}
\hline $\begin{array}{c}\text { Image Satel- } \\
\text { lite }\end{array}$ & Bands & Date & $\begin{array}{c}\text { Reso- } \\
\text { lution } \\
{[\mathrm{m} \times \mathrm{m}]}\end{array}$ & $\begin{array}{c}\text { Pixel } \\
\text { Depth }\end{array}$ & $\begin{array}{c}\text { Image } \\
\text { Source }\end{array}$ \\
\hline $\begin{array}{l}\text { Landsat 5 } \\
\text { TM }\end{array}$ & 4 & $\begin{array}{c}22 / 10 / \\
1972\end{array}$ & $60 \times 60$ & 8 Bit & USGS \\
\hline Landsat 8 & 10 & $\begin{array}{c}17 / 6 / 2 \\
016\end{array}$ & $30 \times 30$ & 16 Bit & USGS \\
\hline Sentinel-2 & 13 & $\begin{array}{c}06 / 1 / 2 \\
020\end{array}$ & $10 \times 10$ & 12 Bit & ESA \\
\hline
\end{tabular}

USGS: U.S. Geological Survey

ESA: European Space Agency

The images pre-processing is the process of making them more suitable for a particular purpose. The image pre-processing of remotely sensed data is essential for image classification, and in the direct linkage between the data and biophysical phenomena and features. This requires several processing steps for better identification of the image features. These steps include atmospheric correction and geometric correction.

For this analysis, supervised classification was used in shoreline extraction since the area of interest is known and clear to be distinguished, i.e. the water and land, so the spectral signatures of classes are developed and then the software assigns each pixel in the image to the type to which its signature is most similar.

The analysis shows that the current average beach width in the study area is about $60 \mathrm{~m}$. However, comparing the images of 1972 and 2016, when the construction of Khan Younis breakwater was started, shows that accretion took place to the area to the south of the study area, where the beach width has 
decreased with 5-15 m. On the other hand, comparing the image of 2016 to the image of 2020 shows that erosion takes place along the shore within the area, given that it is located to the north of the port (See Figure 5). According to this analysis, the average annual erosion rate in the study area during the period between 2016 and 2020 is $2.37 \mathrm{~m}$ per year.

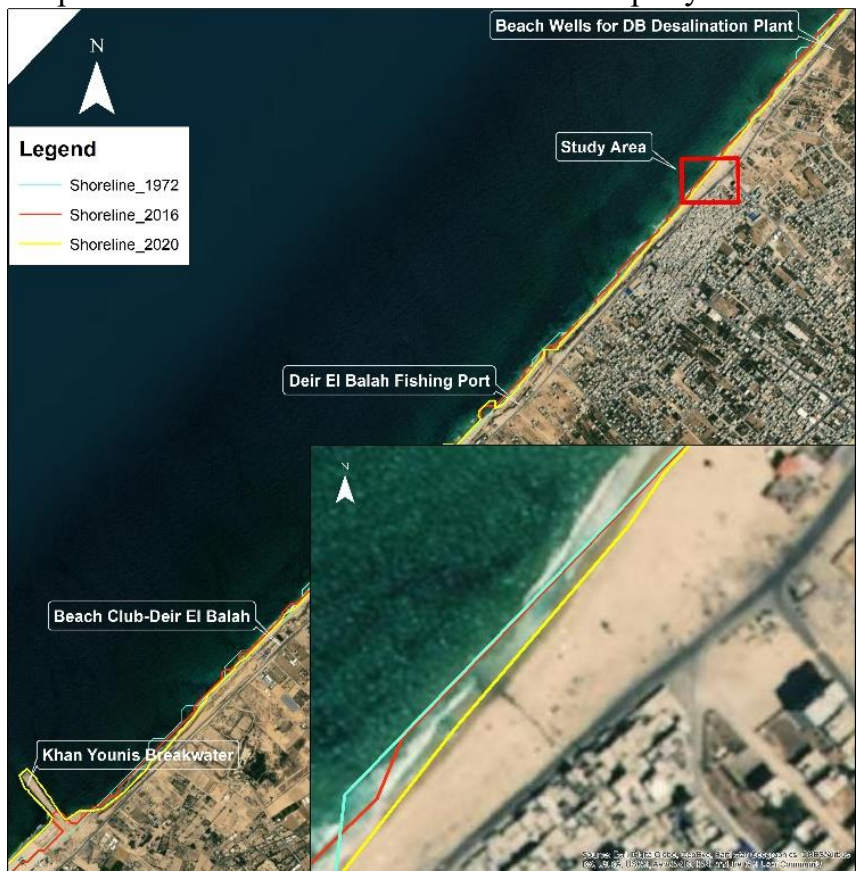

Fig. 5. Shoreline erosion for the study area

An overview of shoreline erosion for the whole coastline of Deir El Balah over the four-year period between 2016 and 2020 , the analysis showed that a maximum shoreline retreat of $40 \mathrm{~m}$ is found to take place at some locations along Deir El Balah shoreline, while a minimum retreat of $1 \mathrm{~m}$ is taking place at some other locations.

In general, an advancing shoreline and growing beach occur south of Khan Younis breakwater, as the littoral sediments transport has been interrupted by the breakwater. On the other hand, a retreating shoreline and eroded beach are present north of the breakwater. These erosion and accretion patterns reveal the natural processes of wave-induced long-shore currents and sediment transport, in addition to the impact of human intervention by coastal structures.

\section{b. Flooding}

According to the local residents of the study area, seawater flooding occurs during heavy storms, where seawater can reach specific locations that were identified during the visit with a ground level near $+4 \mathrm{~m}$ MSL. From residents' observations, the frequency of stormy season was once every ten years, however the return period become shorter these days. Based on the collected data during the site visit and taking into consideration the historical wave records, the area was identified to have a flood risk potential as shown in Figure 6. The estimated flood area is about $5,000 \mathrm{~m}^{2}$ based on the available topographic survey, this area represents about $3 \%$ of the total camp area $\left(160,000 \mathrm{~m}^{2}\right)$. Therefore, the design level of the new recreational area should be slightly above $+4 \mathrm{~m}$ MSL as per the local residents' feedbacks.

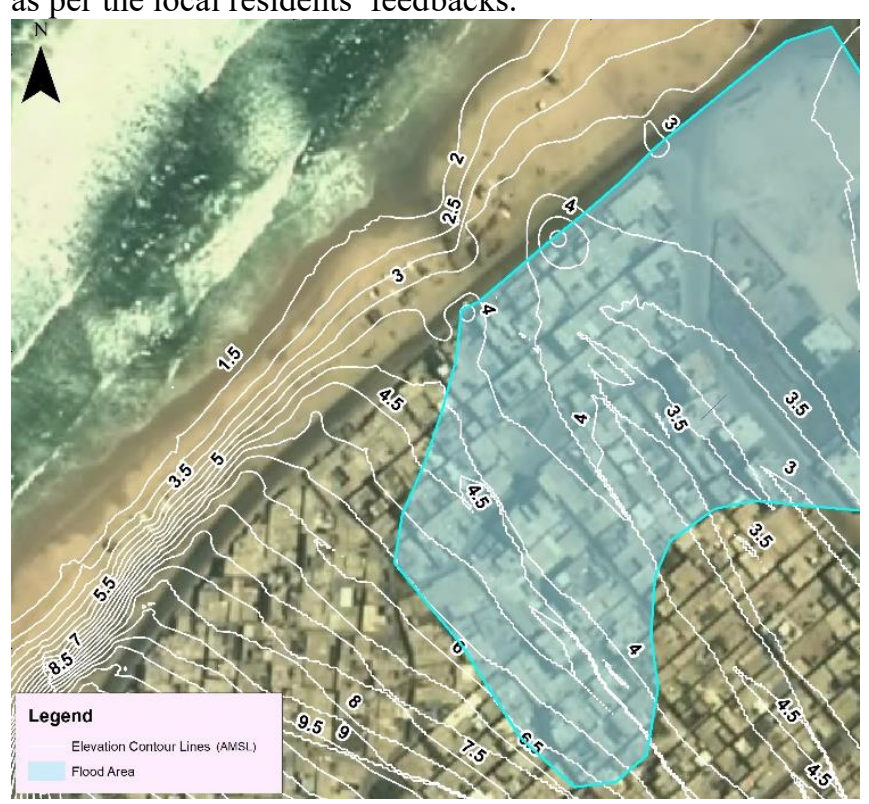

Fig. 6. Location of flooding area

\subsection{Multi criteria analysis}

Three offshore alternatives were addressed, namely: artificial reefballs, concrete cubes, and geotubes. Additional seawall alternative on-shore structure was considered.

Multi criteria analysis was used to assess the alternatives with respect to criteria that capture the key dimensions of the selection process, the main criteria include erosion/scouring control, impact on ecosystem, associated safety risk, acceptability, material availability, construction experience, cost, aesthetic aspects, socio-economic impact, and sustainability.

\section{RESULTS AND DisCUSSION}

Several mitigation measures were analysis using numerical model for Gaza coastal area such as groins, detached offshore breakwaters, and submersed offshore breakwaters [20]. Results show that the offshore-submerged breakwater is an effective structure for preventing sandy beach erosion due to wave and nearshore current actions, and for the landscape of seaview in front of sandy beaches.

\subsection{Geometric characteristic and sizing of offshore breakwater}

Offshore breakwater is a structure constructed parallel with the coast. Even though it is called offshore breakwater, the position of the construction is quite close with the coast, where the construction efficiency is very much determined by the distance between the breakwater and the original coastline. The creat of submerged breakwater is usually below the higher sea level, mean sea level and lower sea level. The breakwater is built to provide protection from wave action and currents in some cases. Breakwaters are constructed to minimize wave action in an area behind the structure. On the coast protected by offshore breakwater, sediment deposit will 
be formed which is called salient. The success of coastal protection using offshore breakwater is determined by salient (Ys) that was formed, see Figure 7, where the height of the salient is determined by the length of breakwater (Ls) and the distance between breakwater and the original coastline or breakwater distance (X). Considering that breakwater is constructed quite close with the coast where the crest-line is almost parallel with the coast or the wave direction is almost perpendicular to the coast [21].

Submerged breakwaters are recommended from environmental and aesthetics perspectives; considering that the targeted area is a tourism place. Moreover, the location of the breakwaters was selected in order stabilize the shoreline off the Deir El Balah camp without causing erosion to the shoreline to the north of the study area.

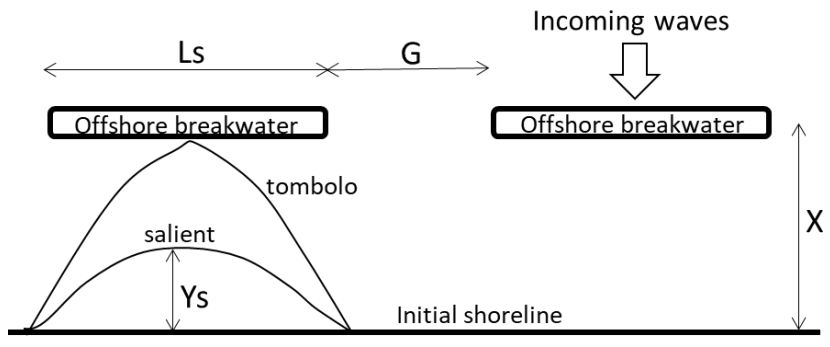

Fig. 7. Offshore breakwater and salient

Most commonly offshore obstruction will cause the shoreline in its lee to protrude in a smooth fashion, forming a salient or a tombolo. This happens because the breakwater lowers the wave height in its lee, reducing the waves' ability to transport sand. As a result, sediment carried by longshore currents and waves accumulates in the breakwater's lee [22]. The level of protection is governed by the size and offshore position of the breakwater, so the size of the salient or tombolo varies in accordance with reef dimensions. Of course, one can expect this kind morphological change only if the sediment is available (from natural sources or as sand nourishment).

Simple geometrical empirical criteria for the layout and shoreline response of detached breakwaters are [23], [24]:

- for tombolo formation: $\mathrm{Ls} / \mathrm{X}>(1.0$ to 1.5$)$

- for salient formation: $\mathrm{Ls} / \mathrm{X}=(0.5$ to 1.0$)$

- for salients with multiple breakwaters: GX/Ls ${ }^{2}>0.5$ where,

Ls is the length of a breakwater

$\mathrm{X}$ is the breakwater distance to the shore,

$\mathrm{G}$ is the gap width between two successive breakwaters

In addition, Rijn et al. [25] has made relation between Ls and $\mathrm{X}$ against the formation of salient or tombolo as per Table 4. The recommended formation is salient, since it allow the current streaming for better seawater quality.

TABLE 4

The value of $L s X$ and salient formation

\begin{tabular}{|c|l|}
\hline Ls $/ \mathrm{X}$ ratio & \multicolumn{1}{c|}{ Formation } \\
\hline$>3$ & Permanent tombolo \\
\hline $2<\mathrm{Ls} / \mathrm{X}<3$ & Permanent or periodic tombolo \\
\hline $1<\mathrm{Ls} / \mathrm{X}<2$ & Well-developed salient \\
\hline
\end{tabular}

\begin{tabular}{|c|l|}
\hline $0.5<\mathrm{Ls} / \mathrm{X}<1$ & Weak to well-developed salient \\
\hline $0.2<\mathrm{Ls} / \mathrm{X}<0.5$ & Incipient to weak salient \\
\hline $\mathrm{Ls} / \mathrm{X}<0.2$ & No effect \\
\hline
\end{tabular}

According to the bathymetric survey at the study site, it was found that the water depth of $1.5 \mathrm{~m}$ is at $18-50 \mathrm{~m}$ crossshore. For a well-developed salient, $\mathrm{X}$ is $30 \mathrm{~m}$ for Ls of $40 \mathrm{~m}$. The width of the gap $(\mathrm{G})$ between two successive breakwaters is usually according to Pilarezyk [26]:

$$
L \leq G \leq 0.8 L_{s}
$$

where, the wave length $L=T(\sqrt{g h})=25 \mathrm{~m}$

Thus, the gap width is $25 \leq G \leq 32$ for detached breakwaters.

The salient can be formed if the submersed breakwater along the study site without gaps, but it is recommended to keep a gap of $25 \mathrm{~m}$ and for small boat navigation.

The size of breakwater is affected by the wave height reaching the water depth of $1.5 \mathrm{~m}$. Therefore, the shoaling, refraction and breaking excel model was used to compute the onshore wave characteristics at water depth of $1.5 \mathrm{~m} \mathrm{MSL}$ (1.95 $\mathrm{m}$ at HWL) for the extreme significant wave height of $10 \mathrm{~m}$ (at deep waters) that may occur in a return period of 100 years (see Table 1). The computed wave height is $0.93 \mathrm{~m}$ at MSL and $1.20 \mathrm{~m}$ at HWL and the following equations were used [27]:

$$
\begin{gathered}
H r s=H o \times K r \times K s \\
K s=\sqrt{\frac{1}{2 n \tanh \left(\frac{2 \pi d}{L}\right)}} \\
K r=\sqrt{\frac{\cos \alpha o}{\cos \alpha}} \\
H b=0.56 d e^{3.5 m}
\end{gathered}
$$

where,

Hrs is the wave height affected by shoaling and refraction

Ho is the wave height at deep-water

$\mathrm{Hb}$ is the breaking wave height

Ks is the shoaling coefficient

$\mathrm{Kr}$ is the refraction coefficient

$\alpha o$ is the wave approaching angle in deep-water

$\alpha$ is the wave angle at local depth

$\mathrm{L}$ is the wave length

$\mathrm{d}$ is the local water depth

$\mathrm{m}$ is the seabed slope

Stability of the submerged breakwater (S), water depth (h), significant wave height (Hs), breakwater crest height (hc'), wave period $(\mathrm{T})$, water density $\left(\rho_{w}\right)$ and rock/concrete density $\left(\rho_{r}\right)$ are main factors that affect the unit size of submerged breakwaters. The following equations were used for sizing the breakwater units [28], [29] and the median mass of concrete unit $\left(\mathrm{M}_{50}\right)$ must be greater than $643 \mathrm{~kg}$ :

$$
\begin{gathered}
\frac{h_{c}^{\prime}}{h}=(2.1+0.1 S) e^{-0.14 N_{s}^{*}} \\
\Delta=\frac{\rho_{r}}{\rho_{w}}-1
\end{gathered}
$$


where,

$$
\begin{gathered}
D_{n 50}=\left(\frac{M_{50}}{\rho_{r}}\right)^{1 / 3} \\
\frac{H_{s}}{\Delta D_{n 50}} s_{p}^{-1 / 3}=N_{s}^{*} \\
s_{p}=\frac{2 \pi H_{s}}{g T^{2}}
\end{gathered}
$$

$N_{S}^{*}$ is the modified stability number,

$D_{n 50}$ is the nominal diameter,

$\Delta$ is the relative buoyant density,

$M_{50}$ is the median mass of unit given by $50 \%$ on mass distribution curve

$s_{p}$ is the local wave steepness.

For any reason at the lowest sea level, where the breakwater structure will behave as a low crest breakwater. Therefore, the structure must be check for low crest breakwater. For design low crest breakwater, water depth (h), crest freeboard (Rc), breakwater slope ( $\cot \alpha$ ), stability Number (Ns), Wa is weight of reef units, $\gamma \mathrm{a}$ is specific weight of reefs, $\mathrm{R}$ is the ratio between reef and water specific weight $=\gamma \mathrm{a} / \gamma \mathrm{w}$ and equilibrium coefficient $\left(\mathrm{K}_{\mathrm{D}}\right)$ are main factors that affect the design of low crest breakwaters. Hudson equations were used for the compuation of the breakwater units [30]:

$$
\begin{aligned}
\Delta & =\frac{\rho_{r}}{\rho_{w}}-1 \\
M_{50} & =\frac{\rho_{r} H^{3}}{K_{D} \Delta^{3} \cot \alpha} \\
D_{n 50} & =\left(\frac{M_{50}}{\rho_{r}}\right)^{1 / 3} \\
S_{p} & =\frac{2 \pi H_{s}}{g T^{2}} \\
R_{p *} & =\frac{R_{c}}{H_{s}} \sqrt{\frac{s_{p}}{2 \pi}} \\
R_{D 50}= & \frac{1}{1.25-4.8 R_{p *}} \\
N_{s} & =\frac{\sqrt[3]{\gamma_{a} H}}{(R-1) \sqrt[3]{W_{a}}}
\end{aligned}
$$

The stability coefficient for artificial reefs or breakwater blocks can be determined from the stability numbers Ns that are obtained from laboratory tests using the following relationship:

$$
N_{s}=\sqrt[3]{(}\left(K_{D} \cot \theta\right)
$$

Thus, the median mass of concrete unit (M50) must be greater than $1,131 \mathrm{~kg}$.

\subsection{Artificial Reefballs Breakwater Alternative}

Reefballs are hollow hemispherical-shaped artificial units, designed for improvement in biological growth and acting as coastal protection structure to control beach erosion. Reefballs are constructed from concrete. This allows reefballs to mix in the marine environment and decreasing potential negative impacts and disturbing the existing ecosystem's growth.

Based on the sizing of breakwater under the water level conditions, it was summarized that the minimum concrete unit weight is $1,162 \mathrm{~kg}$.

Open sea significant wave height of $10 \mathrm{~m}$ for a return period of 100 years was used. The individual units selected for the breakwater were $1.16 \mathrm{~m}$ high reefball units, with base diameter of $1.83 \mathrm{~m}$, and weight of $1364-1,909 \mathrm{~kg}$. Three rows of the selected unit should be installed at distance of $15-40 \mathrm{~m}$ from the shoreline. The length of sets of the reefballs is 120 $\mathrm{m}$. The proposed location of the submerged breakwaters is shown in Figure 9. The breakwater is proposed to be installed in water depth of $1.10-1.50 \mathrm{~m}$, so that the units are $0-0.35 \mathrm{~m}$ below MSL. The tide range in the study area is approximately $0.4 \mathrm{~m}$, i.e. the highest astronomical tide depth and the lowest astronomical tide depth at the selected location are about 1.95 $\mathrm{m}$ and $1.15 \mathrm{~m}$, respectively.

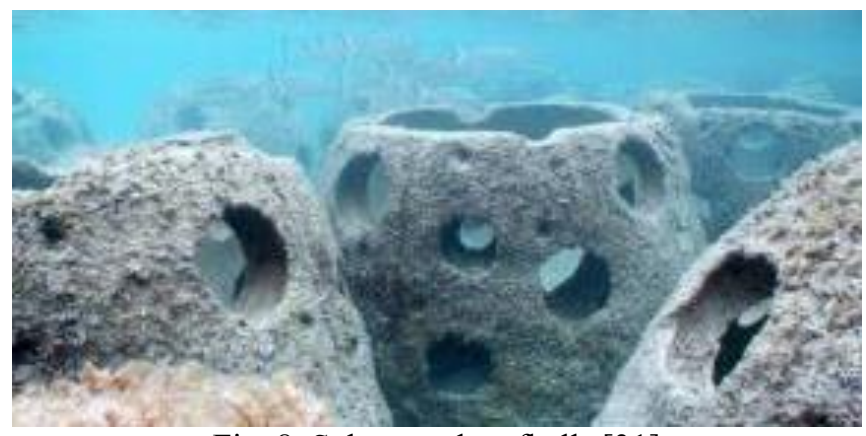

Fig. 8. Submersed reefballs [31]
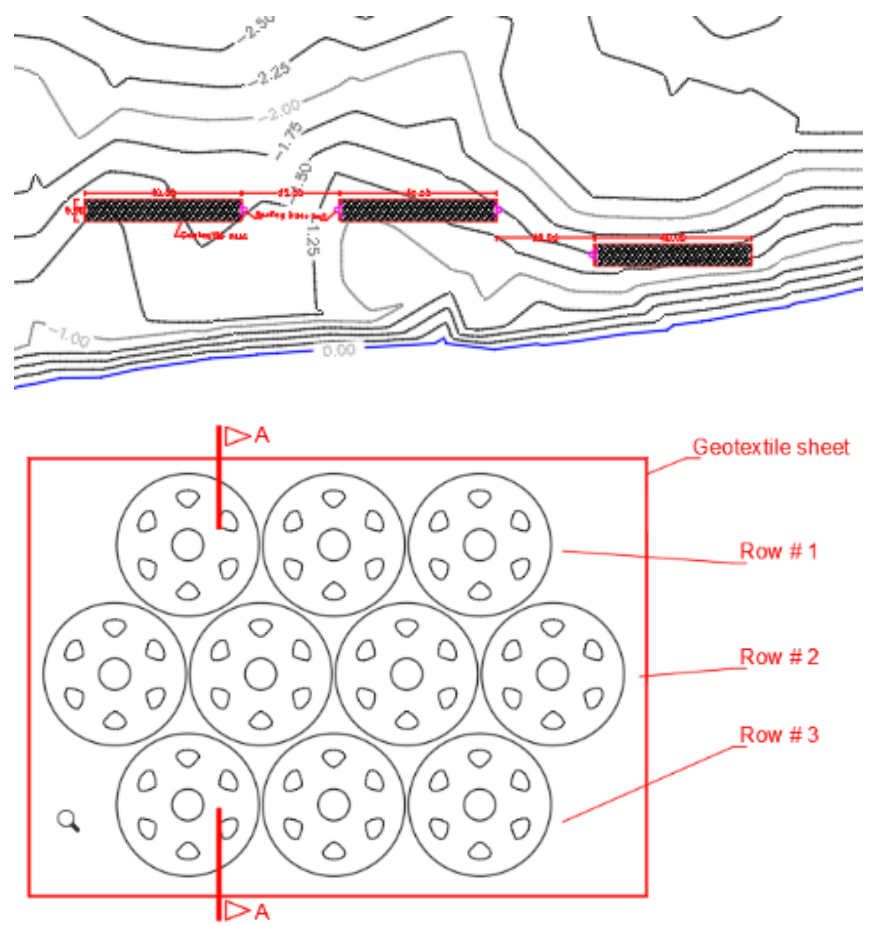


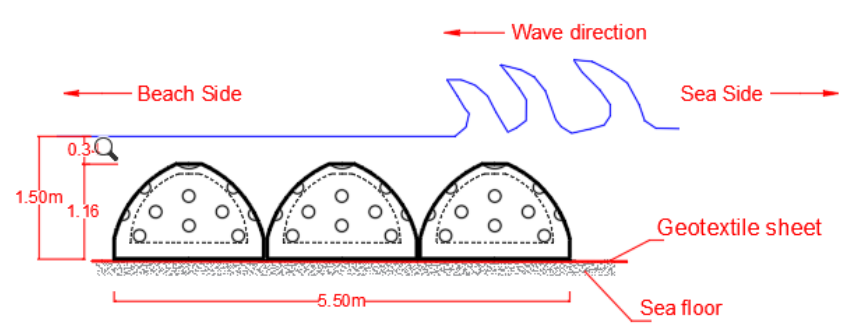

Fig. 9. Location of reefballs breakwater (top) and layout (middle) and section (bottom)

\subsection{Concrete Cube Breakwater Alternative}

Concrete cube breakwater had been widely used to decrease the impact of the wave force that reached the front part of vertical wall breakwater. The gaps between the cubes could reduce the volume of concrete being used. The concrete cubes of $1.00 \mathrm{~m}$ high should be used at water depth $-1.35 \mathrm{~m}$ MSL (1.00 low water level). The concrete volume is $1.0 \mathrm{~m}^{3}(2,400$ $\mathrm{kg}$ ) which is $>1,162 \mathrm{~kg}$.
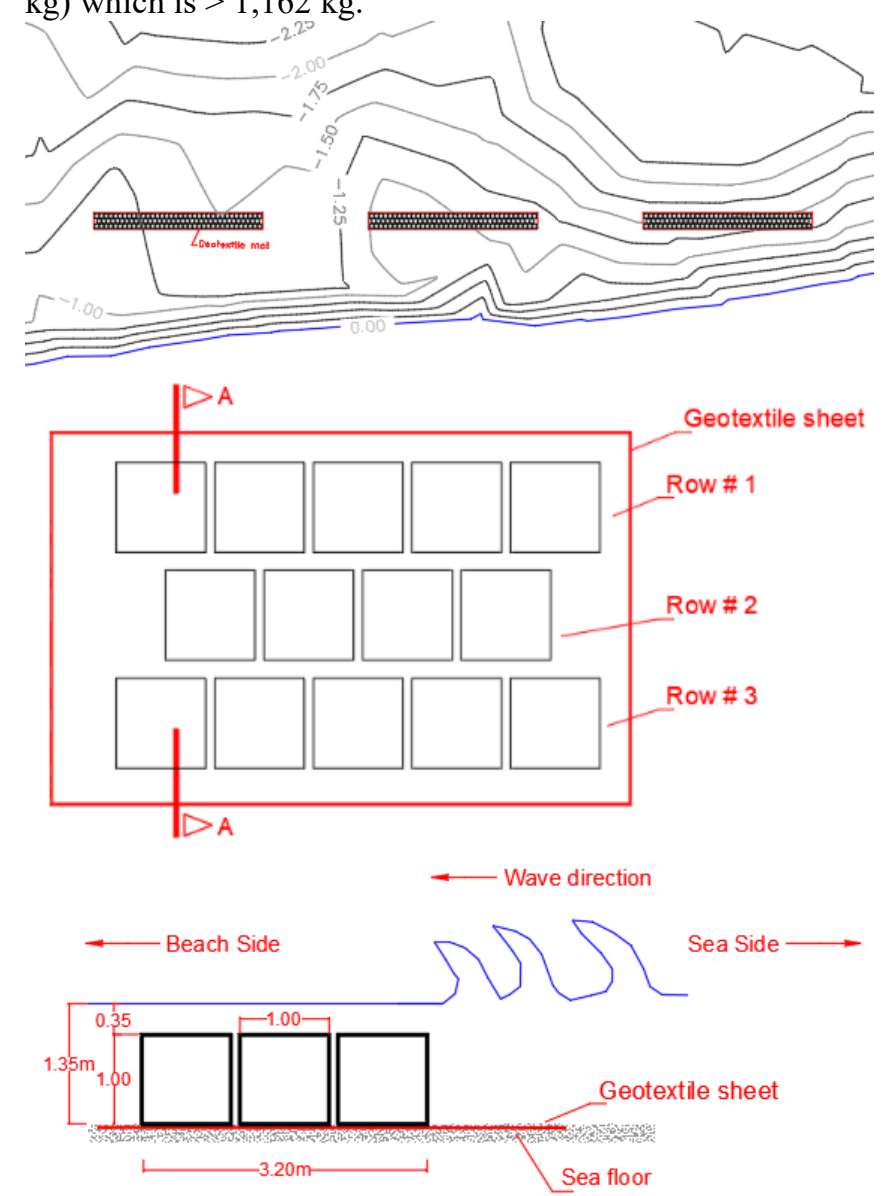

Fig. 10. Location of concrete cubes breakwater (top) and layout (middle) and section (bottom)

\subsection{Geotubes Breakwater Alternative}

For more than 20 years, geotubes, or geosynthetic containers, have been used as an alternative, long-term solution for coastal protection. They have a lesser impact on the environment than hard structures, such as rock and concrete. Geotube systems are also used for land reclamation, island creation, wetlands creation, construction platforms, revetments, dykes, groins, offshore-submerged breakwaters, protecting the cliff along the shore from erosion from wave and wind damage and dewatering container.

The geotube system entails the creation of close-ended tubular containers with filling ports spaced at regular intervals. The containers are hydraulically filled with a sand and water mixture, and transported inside of the tube by hydraulic pressure. Water will dissipate through the permeable fabric, while sand will settle inside the container. Geotube systems are made of woven and composite fabrics in order to meet varying tensile strength, durability and environmental requirements. The tubular shaped geotube containers typically range in diameter from $1.5 \mathrm{~m}$ to $5 \mathrm{~m}$. The size of geotube should satisfy Bezuijen \& Vastenburd equations [32]:

$$
\begin{aligned}
& h \geq(1-\sqrt{1-f}) \cdot d \\
& B \geq h+\frac{1}{2} \cdot \pi \cdot(d-h)
\end{aligned}
$$

where,

$\mathrm{f}$ is the percentage of sand filling, $0.56 \%$ is recommended

$\mathrm{d}$ is the water depth

$h$ is the height of the geotube

$\mathrm{B}$ is the width of the geotube and $\mathrm{B} \geq 2.35 \mathrm{~m}$

For sizing the geosynthetic material strength and as a result of Bezuijen \& Vastenburd equations, the structure to protect the beach should be build with two parallel tubes with a diameter of $1.60 \mathrm{~m}$ and a fill height of $1.0 \mathrm{~m}$ and the circumference of $5.0 \mathrm{~m}$ is recommended. The tubes should be installed with a free board of 0.40 meter. A numerical analysis software called TC Geotube Simulator was used for the sizing the geosynthetic tubes as shown in Figure 11.

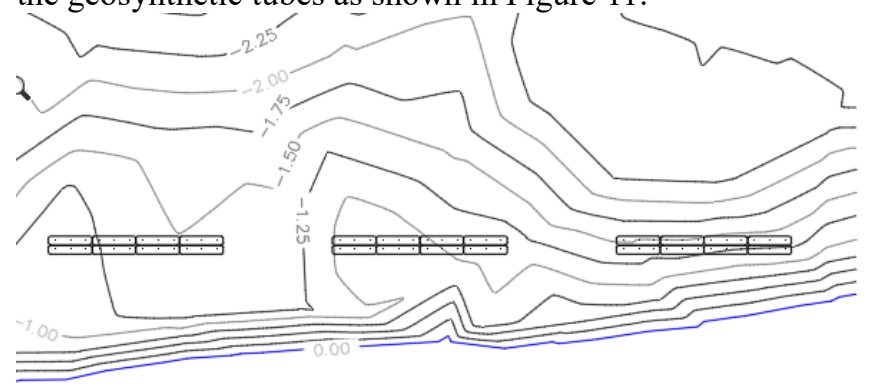



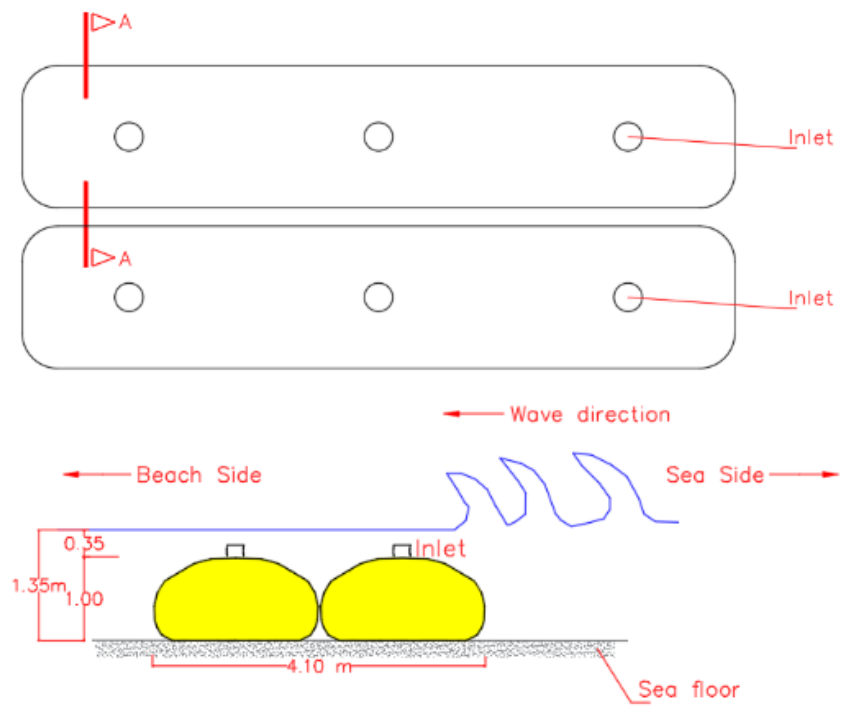

Fig. 11. Location of geotube breakwater (top), layout (middle) and section (bottom)

\subsection{Concrete Seawall Alternative}

Seawall is a protection built along to the seawater barrier. It is usually the preffered protection method for areas where further shore erosion will cause significant damage, such as when roads or buildings are about to fall into the water. Seawalls must be stable and structurally sound as a primary design requirement. They are located at the top of the shore and will be safe during good times (at low water). During times of stress (at high water), they will be exposed to direct wave action. Majority of seawalls are under severe stress. The waves attack the structure, move sand offshore and longshore away from the structure. For long-term, the wave action reflected off the seawall disturbs water near the wall, which can lead to deep scour holes just offshore of the seawall. The scour areas and disturbed flows can be dangerous, and the scour may even excavate the supporting sand from beneath the structure, jeopardizing the wall's stability.

The total length of the seawall is $252 \mathrm{~m}$ in a curvy shape. The existing ground level is about $+3.5 \mathrm{~m} \mathrm{MSL}$, and it was assumed that the beach in front of the seawall will not drifted so that the seawater is deep adjacent to the seawall, i.e. the beach level just at $0.00 \mathrm{~m}$ MSL due to scouring. This because of the actions from Deir El Balah Municipality to dump the area with sand to protect the seawall after storm season.

The structural analysis for the retaining wall for a section at the highest level (+5.00 m MSL) was carried out using a design code of ACI 318-2011. It was concluded that a wall thickness of $0.40 \mathrm{~m}$ is required to support the soil action. The structure was extended to level of $1.0 \mathrm{~m}$ below MSL with a foundation of cross section of $3.4 \times 0.4 \mathrm{~m}$ as shown in Figure 12 .

The proposed top level at different sections of the seawater barrier is $+5.00 \mathrm{~m}$ MSL, which is above the highest observed wave run up level of $+4.0 \mathrm{~m}$ MSL. Therefore, the proposed level is suitable to work as a flood defense and protecting shelters from sea attacks.

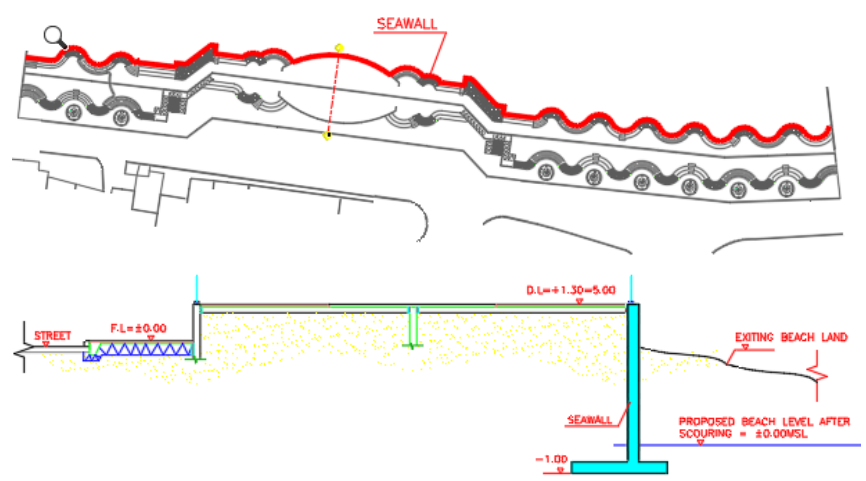

Fig. 12. Sewall layout (top), and section (bottom)

\subsection{Recommended Protection Alternative}

A comparative matrix between the different protections alternatives is presented in Table 5. Multi criteria analysis was used to assess the alternatives with respect to criteria that capture the key dimensions of the selection process. Criteria have been selected based on a literature review, consultations with key stakeholders and the consultant experience (via interviews) of the most important factors when planning, designing, financing, and implementing coastal protection measures. The selected factors can be summarized as follows:

- Erosion and scouring control: this factor assesses the proposed alternative effectiveness in providing the required control of shoreline erosion in the study area.

- Ecosystem: implementing this option would enhance the marine habitat and the ecological value of the study area.

- Risk: implementing this option is expected to cause some safety hazards to people in the area, especially children.

- Acceptability: implementing this protection option would be readily accepted by the community and relevant stakeholders.

- Material availability: each material required to implement this protection option, including additives, is available in the local market/ or could be supplied with no restrictions on its entry to the Gaza Strip.

- Construction experience: implementing this option is possible and the local contractors have the required experience, equipment, human and technical resources to implement this alternative.

- Cost: implementing this protection option is economically feasible and cost effective.

- Aesthetic: implementing this option has aesthetic visual effects on the seaside landscape.

- Socio-economic: implementing this option would have impact upon business activities in the study area (e.g. fishing activities).

- Sustainability: this factor addresses the relevance of the proposed option in the present and future, its resilience against irresponsible behavior of some local residents, and its resilience to future changes.

Quantitative scores ranging from -5 to 5 were used in the evaluation of the proposed alternatives, where -5 is used when the option is highly unfavorable in terms of the specific factor, while 5 is used when the option is highly favorable and zero $(0)$ is used when the option is neutral. 
TABLE 5

Protection alternatives comparison matrix

\begin{tabular}{|l|c|c|c|c|c|}
\hline \multirow{2}{*}{ Factor } & Weight & $\begin{array}{c}\text { Reef- } \\
\text { balls } \\
\text { break } \\
\text { water }\end{array}$ & $\begin{array}{c}\text { Cubes } \\
\text { break- } \\
\text { water }\end{array}$ & $\begin{array}{c}\text { Geo- } \\
\text { tube } \\
\text { break- } \\
\text { water }\end{array}$ & $\begin{array}{c}\text { Sea- } \\
\text { wall }\end{array}$ \\
\hline $\begin{array}{l}\text { Ero- } \\
\text { sion/scouring } \\
\text { control }\end{array}$ & 2 & 5 & 5 & 5 & 0 \\
\hline Ecosystem & 2 & 5 & 2 & 1 & 0 \\
\hline Risk & 2 & -3 & -3 & 0 & 0 \\
\hline Acceptability & 1 & 5 & 4 & 2 & 4 \\
\hline $\begin{array}{l}\text { Material } \\
\text { availability }\end{array}$ & 2 & 5 & 5 & 2 & 5 \\
\hline $\begin{array}{l}\text { Construction } \\
\text { experience }\end{array}$ & 2 & 4 & 5 & 0 & 5 \\
\hline Cost & 2 & 3 & 2 & 5 & 1 \\
\hline Sustainability & 2 & 5 & 5 & 2 & 3 \\
\hline $\begin{array}{l}\text { Aesthetic vis- } \\
\text { ual effect }\end{array}$ & 1 & 4 & 3 & 5 & 2 \\
\hline $\begin{array}{l}\text { Socio-eco- } \\
\text { nomic }\end{array}$ & 1 & 2 & 1 & 0 & 0 \\
\hline $\begin{array}{l}\text { Sum of } \\
\text { weighted } \\
\text { scores }\end{array}$ & 59 & 50 & 37 & 34 \\
\hline
\end{tabular}

Based on this analysis, the recommended alternative is the reefballs offshore breakwaters, where three sets of three-row reef ball submerged breakwaters are proposed to be installed.

\section{Conclusions}

This study proposes a rational solution to the flooding and erosion problems at Deir El Balah Camp, araising from the shoreline imbalance due to climate change and the construction of Khan Younis breakwater in 2016.

Seawater flooding occurs during heavy storms, where seawater can reach a ground level near $+4 \mathrm{~m}$ MSL. From residents' observations, the frequency of stormy season was once every ten years, however the return period become shorter these days.

The shoreline changes between 1972 and 2020 were analyzed using remote sensing and GIS tools, where satellite Landsat and aerial images for the Mediterranean coast of Deir El Balah were acquired for different years covering a time span of 48 years. The analysis shows that erosion takes place along the shore within the area, and the average annual erosion rate in the study area during the period between 2016 and 2020 is $2.37 \mathrm{~m}$ per year.

It is found that the submerged breakwater is the best alternative as a solution to the erosion problem at Deir El Balah beach as it has no adverse effects on the ecosystem, quite the contrary it is environmental friendly alternative especially if we designed it as "artificial reef", it will enrich the marine environment and give a beauty shape, moreover it will protect the shoreline and provides the beach with new accretion areas.

\section{ACKNOWLEDGMENT}

I would like to express my thankfulness to all those who gave me the possibility to accomplish this study. I am deeply indebted to Israa Abushaban, Mohamed Abdrabou and Dr. Amjad Jarada for their continuous valuable effort during data collection and data processing.

\section{REFERENCES}

[1] M. Abualtayef, S. Ghabayen, A. Foul, A. Seif, M. Kuroiwa, Y. Matsubara, and O. Matar, "The Impact of Gaza Fishing Harbor on the Mediterranean Coast of Gaza". Journal of Coastal Development, Vol. 16, no. 1, pp. 1-10, 2012

[2] K. Zhang, B.C. Douglas, and S.P. Leatherman, "Global Warming and Coastal Erosion". Climatic Change, Vol. 64, Article 41, 2004

[3] A. Toimil, I. J. Losada, R. J. Nicholls, R. A. Dalrymple, and M. J.F. Stive, "Addressing the challenges of climate change risks and adaptation in coastal areas: A review". Coastal Engineering, Vol. 156, Article 103611, 2020

[4] B. R. Silliman, Q.He, C. Angelini, C. S. Smith, M. L. Kirwan, P. Daleo, and J. van de Koppel, "Field Experiments and Meta-analysis Reveal Wetland Vegetation as a Crucial Element in the Coastal Protection Paradigm". Current Biology, Vol. 29, no. 11, pp. 1800-1806.e1803, 2019

[5] N. G. Rangel-Buitrago, G. Anfuso, and A. T. Williams, "Coastal Erosion along the Caribbean Coast of Colombia: Magnitudes, Causes and Management". Ocean \& Coastal Management, Vol. 114, pp. 129-144, 2015

[6] S. M. Arens, J. P. Mulder, Q. L. Slings, L. H. Geelen, and P. Damsma, "Dynamic Dune Management, Integrating Objectives of Nature Development and Coastal Safety: Examples from the Netherlands". Geomorphology, Vol. 199, pp. 205-213, 2013

[7] A. V. Hedge, "Coastal Erosion and Mitigation Methods Global State of Art”. Indian Journal of Geo-marine Sciences, Vol. 39, no. 4, pp. 521-530, 2010

[8] H. Zaqoot, S. Hujair, Q. Ansari, and S. Khan, "Assessment of Land-based Pollution Sources in the Mediterranean Sea along Gaza Coast - Palestine", In book: Energy, Environment and Sustainable Development, springer-Verlag/Weir, Editor: M. A. Uqaili and H. Khanji, 2012

[9] M. Shatat, K. Arakelyan, O. Shatat, T. Forster, A. Mushtaha, and S. Riffat, "Low Volume Water Desalination in the Gaza Strip - Al Salam Small Scale RO Water Desalination Plant Case Study". Future Cities and Environment, Vol. 4, no. 1, Article 11, 2018

[10] I.A. Abuamra, A.Y.A. Maghari, and H.F. Abushawish, "Medium-term Forecasts for Groundwater Production and Rainfall Amounts (Deir El-Balah City as a Case Study)". Sustain. Water Resour. Manag., vol. 6, Article 82,2020 
[11] A. Masria, M. Abualtayef, and A. Seif, "Hydro-morphological Simulation for Blue Beach, Gaza Strip, Palestine". Innovative Infrastructure Solutions, Vol. 6, Articl 99, 2021

[12] V. B. Nguyen, "Effect of Particle Size on Erosion Characteristics". Wear, Vol. 348, pp.126-137, 2016

[13] M. Abualtayef, A. Foul, S. Ghabayen, A. F. Rabou, A. Seif, and O. Matar, "Mitigation Measures for Gaza Coastal Erosion". Journal of Coastal Development, vol. 16, no. 2, pp. 135-146, 2013

[14] Netherlands Ministry of Economic Affairs and Palestinian National Authority, NMEA-PNA, "Port of Gaza: Basic Engineering Study". Final Report, 1994

[15]D. S. Rosen, "Assessing Present and Future Mediterranean Sea Level Rise Impact on 'Israel's' Coast and Mitigation Ways against Beach and Cliff Erosion”. Coastal Engineering Proceedings, February 2011

[16] D. S. Rosen, "A Summary of the Environmental and Hydrographic Characteristics of the Mediterranean Coast of Israel”. Israel Oceanographic \& Limnological Research, National Institute of Oceanography, Technical Report, 2001

[17] S. Brenner, "High-Resolution Nested Model Simulations of the Climatological Circulation in the Southeastern Mediterranean Sea”. Annales Geophysicae, vol. 21, pp. 267-280, 2003

[18] Israel Oceanographic and Limnological Research, IOLR, "Seawater Characteristics at Ashkelon". Technical Report, 2016

[19] I. A. Hunt, "Design of Sea Walls and Breakwaters". $T$. American Socity of Civil Engineering, Vol. 126, pp. 542570, 1959

[20] M. Abualtayef, A. Foul, S. Ghabayen, A. F. Rabou, A. Seif, and O. Matar, "Mitigation Measures for Gaza Coastal Erosion". Journal of Coastal Development, Vol. 16, no. 2, pp. 135-146, 2013

[21] S. Hutahaean, "Salient Calculation at the Single Offshore Breakwater for a Wave Perpendicular to Coastline using Polynomial Approach". International Journal of Advanced Engineering Research and Science, Vol. 7, no. 1, pp. $156-161,2020$

[22] S. Mead and K. Black, "Wave Rotation for Coastal Protection". Asian and Pacific Coasts 2003, pp. 1-12, 2004

[23] M. M. Harris, and J. B. Herbich, "Effects of Breakwater Spacing on Sand Entrapment". Journal of Hydraulic Research, Vol. 24, no. 5, pp. 347-357, 1986

[24] W.R. Dally, and J. Pope, "Detached Breakwaters for shore protection". Technical Report CERC-81-61, U.S. Army Corps of Engineers, Vicksburg, Mississippi, 1986

[25] L. C. Rijn, J. S. Ribberink, J. J. van der Werf, and D. J. R. Walstra, "Coastal Sediment Dynamics: Recent Advances and Future Research Needs". Journal of Hydraulic Research, Vol. 51, no. 5, pp. 475-493, 2013

[26] K. W. Pilarczyk, "Design of Low-crested Submerged Structures-An Overview. Proceeding of 6th International Conference on Coastal and Port. Engineering in Developing Countries, Pianc-Copedec, Colombo, Sri-Lanka, pp. $1-16,2003$
[27] J W. Kamphuis, "Introduction to Coastal Engineering and Management". Second Edition, Advanced series on ocean engineering Vol. 30, Pages: 564, World Scientific Press, 2010

[28] J. van der Meer, and K. Pilarczyk, "Stability of Lowcrested and Reef Breakwaters". Coastal Engineering Conference, Chapter 103, pp.1375-1388, 1990

[29] J. van der Meer, "Rock Slopes and Gravel Beaches under Wave Attack". Ph.D. Thesis, Delft University, the Netherlands, 1988

[30] R. Y. Hudson, F. A. Herrmann, R. A. Sager, R. W. Whalin, G. H. Keulegan, C. E. Chatham and L. Z. Hales, "Coastal Hydraulic Models". Special Report No. 5, US Army Engineer Waterways, Experiment Station, Vicksburg, Mississippi, 1979

[31] M. Buccino, I. Del Vita, and M. Calabrese, "Engineering Modelling of Wave Transmission of Reef Balls". Journal of Waterway, Port, Coastal and Ocean Engineering, Vol. 140, no. 4, pp. 04014010, 2014

[32] A. Bezuijen and E.W. Vastenburd, "Geosystems: Design Rules and Applications". First edition CRC Press/Belkama, 2013

Mazen Abualtayef is an Associate Professor of coastal engineering in environmental engineering department at the Islamic University of Gaza. He is a water engineering expert and got a versatile experience during his 24 years of experience of working in managing, designing and supervising of infrastructure projects especially water and coastal projects. He participates in teaching many courses such as port and coastal engineering, brine management, renewable energy for desalination, O\&M of water-sewerage-stormwater networks, engineering economics, surveying and GIS, environmental modeling, fluid mechanics, hydraulics, numerical analysis. 